\title{
Decrystallization with high current pulses technique for capacity restoration of industrial nickel-cadmium battery
}

\author{
M. P. Martin', Asmarashid Ponniran², R. A. Rahman³, N. S. M. Ibrahim ${ }^{4}$, A. Eahambram5, \\ M. H. Aziz ${ }^{6}$, A. M. Yassin ${ }^{7}$ \\ ${ }^{1,2,4}$ Faculty of Electrical and Electronic Engineering, Universiti Tun Hussein Onn Malaysia, Malaysia \\ ${ }^{3}$ Faculty of Mechanical and Manufacturing, Universiti Tun Hussein Onn Malaysia, Malaysia \\ ${ }^{5,6,7}$ Renewcell (M) Sdn. Bhd., Bandar Bukit Raja, Malaysia
}

\begin{tabular}{|c|c|}
\hline Article Info & ABSTRACT \\
\hline Article history: & The process of crystallization occurred due to the process of charging and \\
\hline Received Feb 19, 2020 & $\begin{array}{l}\text { discharging during the usage of the Nickel-Cadmium (Ni-Cd) battery where } \\
\text { crystalline formed on the surface of the battery plate. This situation causes }\end{array}$ \\
\hline Revised Apr 5, 2020 & the impedance of the Ni-Cd battery increased and contribute to the increment \\
\hline Accepted Apr 20, 2020 & $\begin{array}{l}\text { of the battery temperature and battery impedance. High battery temperature } \\
\text { will cause the performance of Ni-Cd battery deteriorates. Therefore, this }\end{array}$ \\
\hline Keywords: & $\begin{array}{l}\text { study is investigated on the performance of industrial Ni-Cd battery during } \\
\text { the process of crystallization and de-crystallization with high current pulses. }\end{array}$ \\
\hline Capacity loss & By this technique, it is capable to break the formed crystalline to recover \\
\hline Current pulses & $\begin{array}{l}\text { back the capacity loss and enhanced the performance of N1-Cd battery. } \\
\text { Therefore, the study results shown that the life cycles and capacity of the Ni- }\end{array}$ \\
\hline De-crystallization & Cd battery increased up to $41 \%$ of its capacity after the de-crystallization \\
\hline Nickel-Cadmium battery & take place by injecting high current pulses. Consequently, the life span of the \\
\hline High battery temperature & Nickel-Cadmium battery enhanced, and the battery is revived. \\
\hline
\end{tabular}

This is an open access article under the CC BY-SA license.

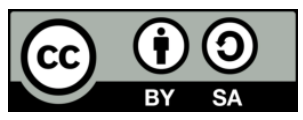

\section{Corresponding Author:}

Asmarashid Ponniran,

Faculty of Electrical and Electronic Engineering,

Universiti Tun Hussein Onn Malaysia,

86400 Parit Raja, Johor, Malaysia.

Email: asmar@uthm.edu.my

\section{INTRODUCTION}

In recent years, high needs in the maintenance of batteries is emerging due to the energy transition from vehicles that used combustion as energy to electrical energy [1-5]. With this the emission of greenhouse gases is reduced as it become major concern issues nowadays [6-9]. Battery is a technology that capable to transform chemical energy to electrical. The energy stored in the battery is used through the process of oxidation-reduction where the movement of the electron produced an electromotive force which also known as voltage. Batteries are generally classified as either primary or secondary. Primary batteries are the type that may only use one time because the active materials are used up when the cell discharges. Once the primary battery is discharged completely, it is discarded. Meanwhile, the secondary batteries may be used repeatedly because the chemical reaction which produces electrical energy can be reversed by recharging the battery. Ni-Cd batteries is one of the secondary batteries that have used in massive applications in different industrial area especially in transportation and UPS due to their high performance and able to recharge rapidly [10]. Moreover, the Ni-Cd battery have high energy density.

In the $\mathrm{Ni}-\mathrm{Cd}$ cell, nickel oxyhydroxide $(\mathrm{NiOOH})$ is the charged active material in the positive plate. During discharge, the charge nickel hydroxide goes to a lower valence state by accepting electrons from 
external circuit Ni-Cd battery. Meanwhile, cadmium $(\mathrm{Cd})$ metal is the charge active material in the negative plate. During discharge it is oxidize to cadmium hydroxide and release electron to the external circuit. also use aqueous solution of potassium hydroxide as their electrolyte. These reactions occur in the electrolyte which act as medium of ion transfer only, therefore there is no significant changes that can observe during the charge or discharge cycle.

However, the performance of the Ni-Cd batteries degraded over period after undergo charging and discharging process due to the formation of crystalline [11]. Crystallization is an electrochemical reaction that occurs when the Ni-Cd battery in discharge state that build gradually on the battery cell plates [12-13]. During the discharging process, the Nickel-Hydroxide in state of liquid is transform into solid crystalline and formed on the plate surface of the battery. As the formation of the crystalline is accumulated, the size of the surface area of the plate decrease and the internal impedance of the Ni-Cd battery is higher. Thus, the battery temperature also increased [14]. This condition cause the Ni-Cd battery suffered from capacity loss as the life expectancy to be correspondingly reduced [15-17]. The formation of the crystalline also contribute as factor that cause the memory effect in the Ni-Cd battery [18-19].

In order to overcome this issue, the process of de-crystallization is required. There are few researches have been conducted to improve the performance of Ni-Cd battery. One of the ways is using the conventional way where additives such as carbon powder, carbon nanotubes, titanium dioxide, glass fibres, silicon dioxide, aluminium oxide and boric acid [20-22] is added. Other than that, the application of low current and high current pulses method to restore the capacity of the batteries is also possible [23, 24]. However, these methods have own merits and demerits in terms of the effectiveness of the technique. Therefore, in this study, de-crystallization with technique of high current pulses is chosen as study focus where the injected high current pulses force the electrons at the battery plate move and chemical reaction occurs. To generate high current pulses during de-crystallization, a power converter $[25,26]$ is considered to generate DC pulses as the main power supply from the main grid in AC state.

There are two types of crystalline which are soft crystalline and hard crystalline Normally, most of the soft crystalline able to break down into electrolyte through normal process of discharging. But, softcrystalline that unable to break during the discharging process will form hard-crystalline on the battery plate after period of time. Therefore, high current pulses are required injected to the Ni-Cd battery so that some of the hard crystalline in solid state is able to break down and transform into liquid state of Nickel-Hydroxide. Hence, the aim of this study is to observe the significant parameters of the Ni-Cd battery such as battery group voltage, discharging time and battery capacity during before and after de-crytallization by using technique of high current pulses.

The remainder of the paper is organized as follows. A briefly technical framework and experimental block diagram description is discussed in Section 2. The results and analysis are deliberated in Section 4. Lastly, Section 5 summarizes all the findings.

\section{DESCRIPTION OF DE-CRYSTALLIZTION SYSTEM \\ 2.1. Battery Regenerator}

Battery regenerator is used to help the battery undergo capacity restoration (reviving battery) in order to improve the performance of the degraded batteries and extend the battery life. For Ni-Cd battery, decrystallization process is one of the refurbishment techniques to reverse the crystallization of the $\mathrm{Ni}-\mathrm{Cd}$ battery. De-crystallization is achieved by sending high current pulses that break down the crystalline layer formed by amorphous Nickel-Hydroxide. The battery regenerators restore the lost battery capacity through carefully controlled current pulses. These current pulses sent by the rectifier controller is sufficient to break soft-crystallization and hard-crystallization of Nickel-Hydroxide. By this, the capacity of the regenerated battery is enhanced, and the life cycles of the battery extend. Besides, the process of the de-crystallization also can achieve by sending low frequency of electrical pulses. This result the capacity of the regenerated battery and the life span of the battery is increased.

\subsection{High Current Pulses}

During the process of de-crystallization, current pulses with high-powered is applied to the Ni-Cd battery to break the formed crystalline according to the feedback of the battery. High battery voltage indicates high internal impedance which indicate the crystalline formation on the surface of the plate is high. Therefore, high current pulses in range of $100 \mathrm{~A}$ to $300 \mathrm{~A}$ is required. However, if the voltage detection is low, the working principle that apply is vice versa. The block diagram on the working principle of high current pulses in de-crystalline the Ni-Cd battery is shown in following Figure 1. 


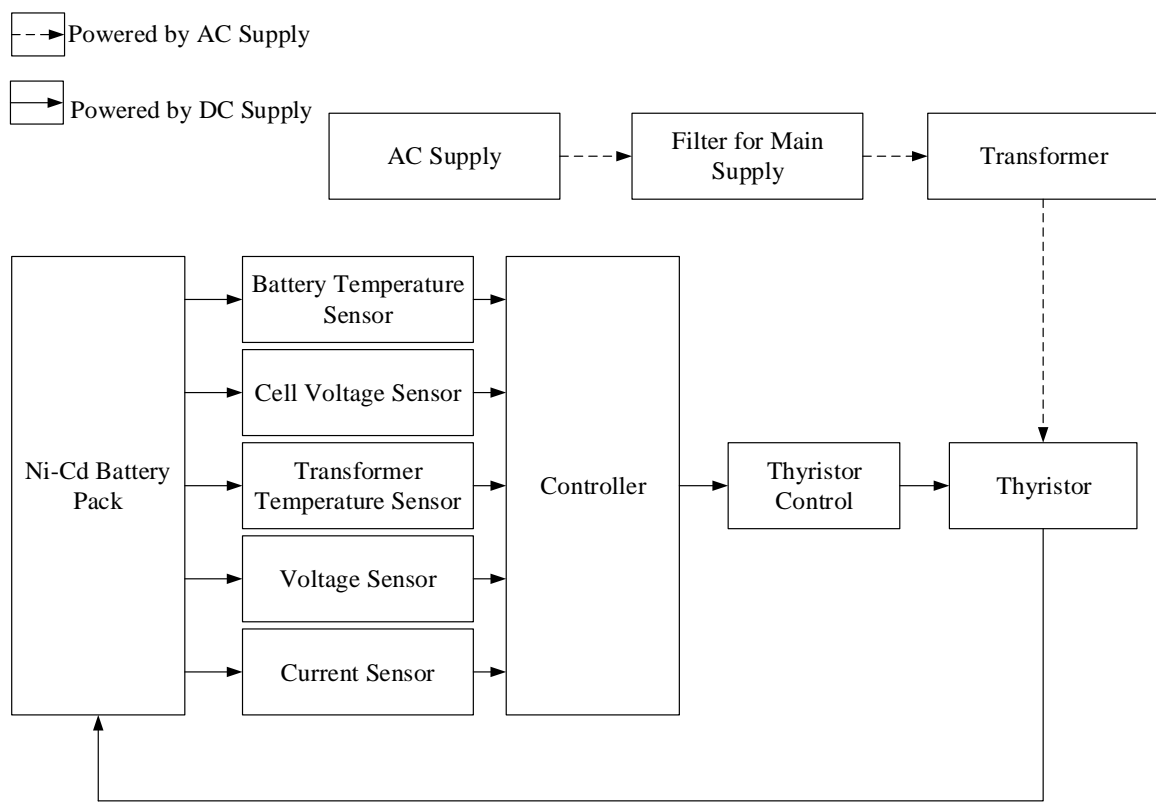

Figure 1: Block diagram on working principle of the revived Ni-Cd battery system.

From Figure 1, the buck-boost transformer is supplied with 3-phase AC power supply to powered up the thyristor. As the battery is connected to the system, the related data such as battery cell temperature, voltage across the reference cell, transformer temperature, battery voltage and battery current is send to the controller of the system. Then, the thyristor controller analyze the signals feedback from the controller to regulate the suitable current pulses to break the crystalline. The thyristor generate current pulses based on the suitable fire switching scheme. This process is repeated until the referenced battery cell is achieved it desired voltage. In the battery technology, temperature is one of the important parameter to observe in order to preserve the performance of the regenerated battery [27-28]. Therefore, the regenerator machine must capable to detect the cell temperature of reference battery. If the temperature is reached the reference temperature, the used machine will increase the period of the pulsation in order to allow the temperature of the reference battery below than the reference temperature.

\subsection{Experimental Setup}

The flowchart of the experiment process on the reviving the Ni-Cd batteries by restoring charge capacity of the battery is shown in Figure 2. Meanwhile, the experimental setup of the research is shown in Figure 3. The selected $\mathrm{Ni}$-Cd battery bank have been used in railway transportation as an emergency back-up source for 5 years and the specifications of the battery is given in Table 1. The specifications used during the Ni-Cd battery regeneration is stated as in Table 2 .

Table 1. Specifications of selected Ni-Cd battery

\begin{tabular}{cc}
\hline Items & Description \\
\hline Battery Brand & Saft \\
Battery Production Year & 2009 \\
Nominal Capacity & $140 \mathrm{AH}$ \\
Cell Voltage & $1.2 \mathrm{~V}$ \\
Discharge Rate & $5 \mathrm{H}$ \\
Cell Number & 24 \\
\hline
\end{tabular}

Table 2: Specifications of the Ni-Cd Battery Regeneration

\begin{tabular}{cc}
\hline Items & Parameter \\
\hline Nominal Capacity & $150 \mathrm{AH}$ \\
Cell Voltage & $1.2 \mathrm{~V}$ \\
Group Voltage & $38 \mathrm{~V}$ \\
Items & Parameter \\
\hline
\end{tabular}




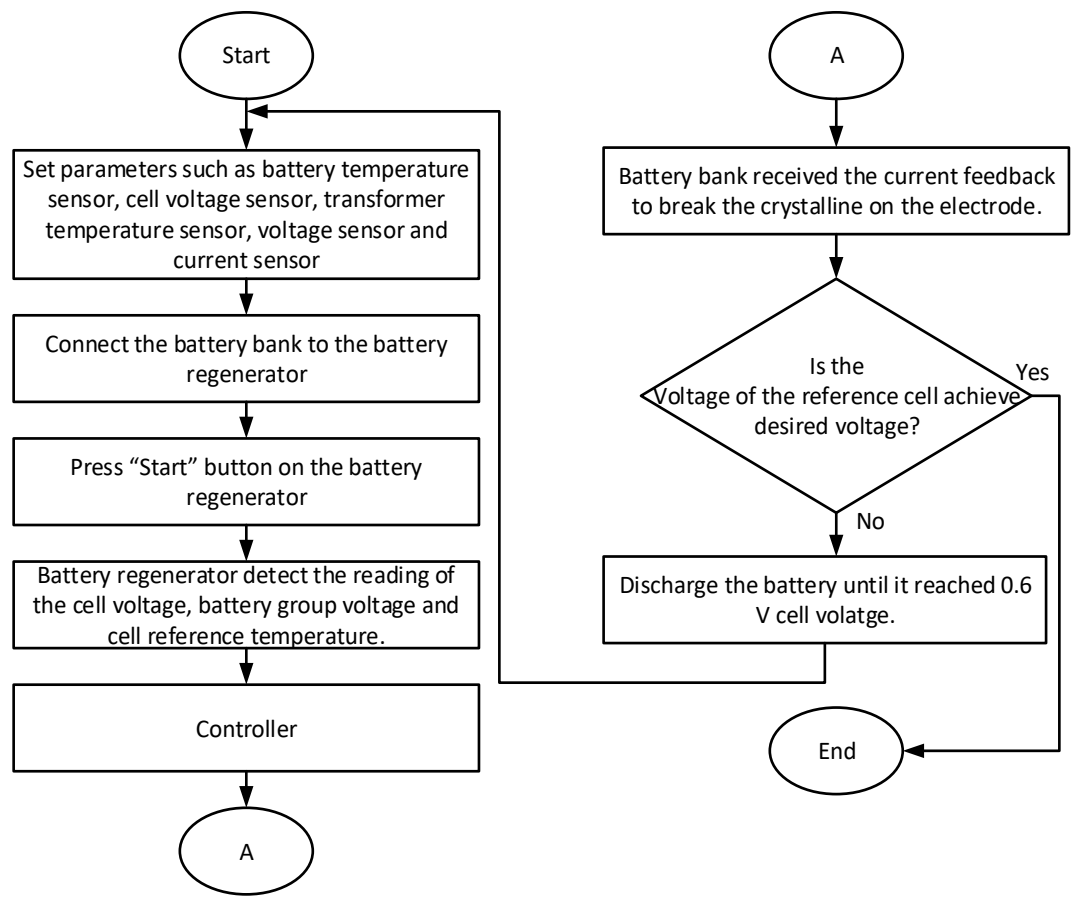

Figure 2: Flowchart for the reviving battery process.

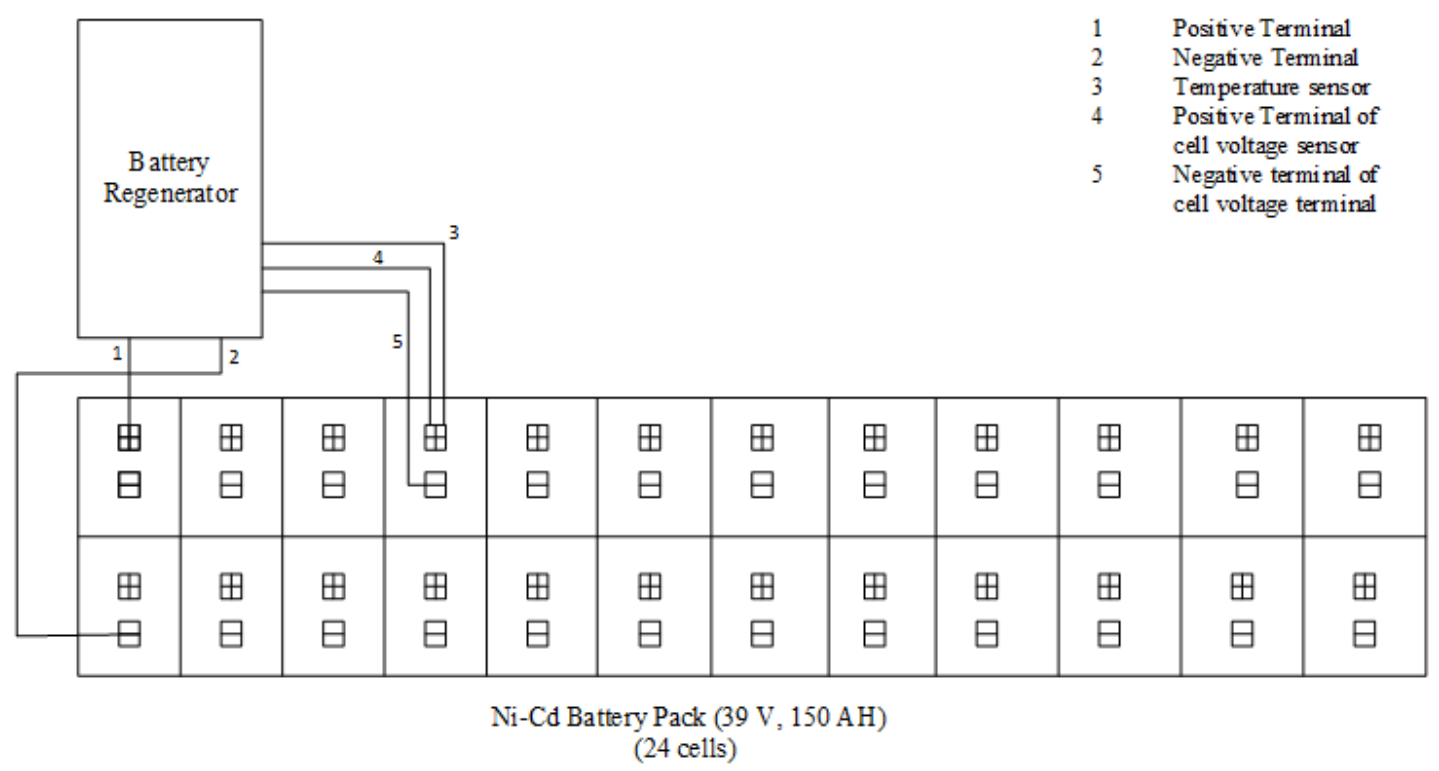

Figure 3: Block diagram of battery regeneration setup.

When the Ni-Cd batteries is received, proper inspections are performed on the battery by filling the service form, battery cleaning and repair any visible external damage. Then, the received Ni-Cd batteries will undergo complete charging process by connecting it to the charger machine with set parameters. After the charging process is complete, the Ni-Cd batteries undergo for discharging process by using discharger machine with set parameters. During the discharging process, the Ni-Cd batteries undergo deep discharge where the discharge voltage is set to $0.6 \mathrm{~V}$ to clear the memory effect [10]. After completing the discharging process, the batteries were ready to enter regeneration process. The process is repeated until the desired battery voltage which is above $0.8 \mathrm{~V}$ is achieved. 


\section{RESULTS AND ANALYSIS}

In this section, results analysis on de-crystallization of Ni-Cd battery is discussed. Before the decrystallization process is start, capacity test is performed on the Ni-Cd battery with $80 \%$ of depth of discharge to identify the initial performance of the Ni-Cd batteries. The observed parameters are battery group voltage, discharged time and capacity of the battery. The graph of discharged battery group voltage before and after de-crystallization is shown in Figure 4.

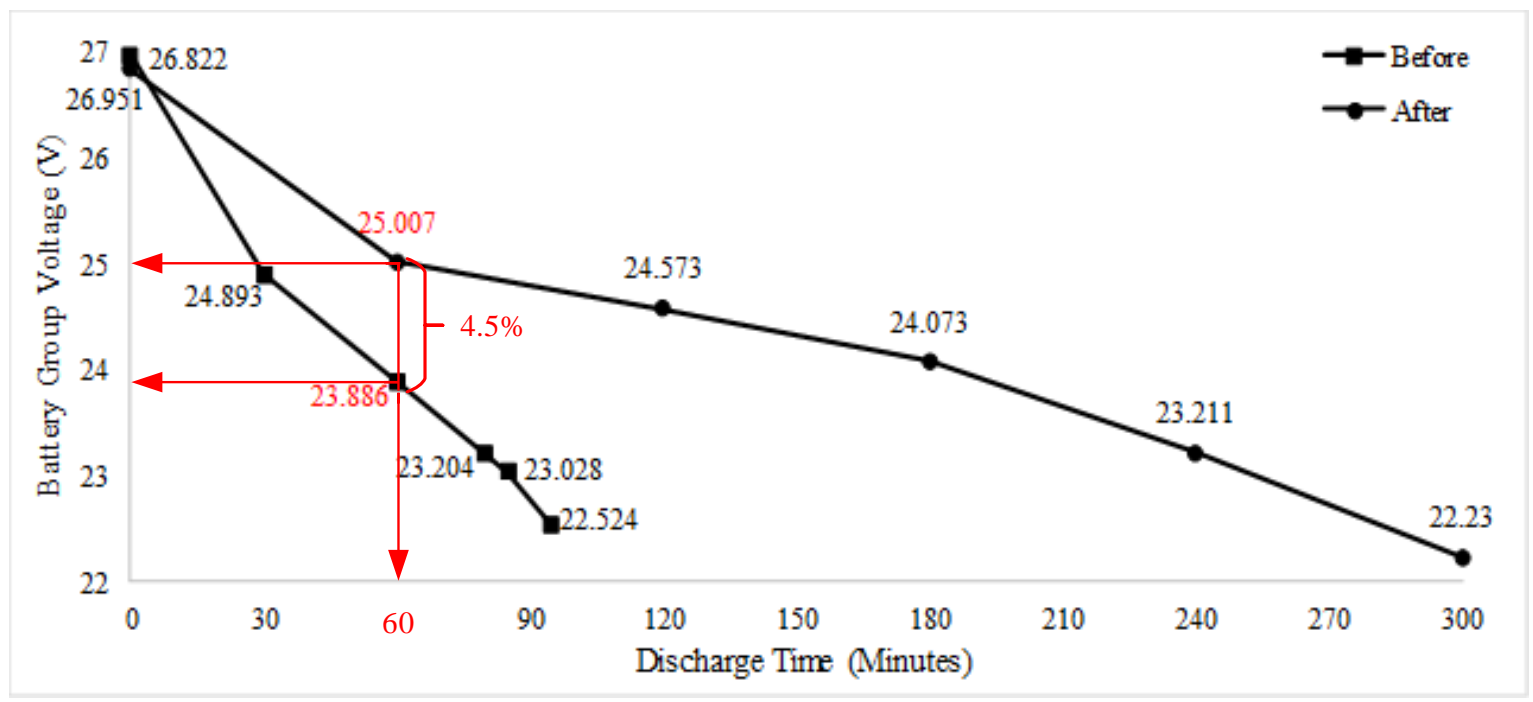

Figure 4: Graph of battery group voltage against discharge time.

From the graph that presented in the Figure 4, it is observed that the trend of the Ni-Cd battery total voltage is decrease against time. Before the process of decrystallization, most of the Ni-Cd battery voltage is on the average of $1.3 \mathrm{~V}$ and the total $\mathrm{Ni}-\mathrm{Cd}$ battery voltage is $26.95 \mathrm{~V}$. After an hour of discharged before decryatallization, the battery group voltage dropped $10.9 \%$ from the initial battery group voltage and the time taken for the Ni-Cd battery bank complete discharged is 95 minutes. This happened due to the accumulation of crystalline at the surface of the Ni-Cd battery electrode which result the internal resistance of the Ni-Cd battery is high and create memory effect. The high internal resistance in the Ni-Cd battery cause the battery unable to deliver the current to the load effectively. Moreover, high internal resistance in the Ni-Cd battery leads to increment of temperature and voltage to drop. Therefore, the $\mathrm{Ni}-\mathrm{Cd}$ battery is required to undergo the de-crystalline process to break the crystalline formation on the battery plate and deep discharged to clear the memory effect.

After the process of de-crystallization with high current pulses technique, the battery voltage dropped $7.2 \%$ from the initial battery group voltage after an hour and the total discharged time is 300 minutes. From this results, the difference percentage of the battery group voltage at $4.5 \%$ between before decrystallization and after de-crystalline after an hour is observed. Moreover, the discharged time after the Ni$\mathrm{Cd}$ battery bank undergo de-crystallization is extended for 205 minutes. This indicated that the technique of high current pulses is able to enhance the capacity of the Ni-Cd battery and thus the life cycles of the Ni-Cd battery is improved. This is because the crystalline that formed on the surface of the electrode is broke by the injected high current pulses which up to $150 \mathrm{~A}$ into the Ni-Cd battery. Hence, the discharge capacity of the $\mathrm{Ni}-\mathrm{Cd}$ battery is increased from $22 \mathrm{AH}$ to $58 \mathrm{AH}$. The performance parameter of the Ni-Cd batteries before and after regeneration is tabulated as in Table 3.

Table 3: The overall performance parameter of Ni-Cd batteries.

\begin{tabular}{lccc}
\hline & Before Regeneration & After Regeneration & Difference \\
\hline Total discharge capacity & $22 \mathrm{AH}$ & $58 \mathrm{AH}$ & $36 \mathrm{AH}$ \\
Time of discharge & 1 hour 32 minutes & 4 hours 15 minutes & 2 hours 40 minutes \\
Percentage of capacity & $(95$ minutes $)$ & $(255$ minutes $)$ & $(160$ minutes $)$ \\
\hline
\end{tabular}


With reference from Table 3, it is observed that the time of discharge is enhanced from 95 minutes to 255 minutes and capacity percentage of the $\mathrm{Ni}-\mathrm{Cd}$ battery is increased for $41 \%$. Besides, the total discharge capacity of the Ni-Cd battery is improved from $22 \mathrm{AH}$ to $58 \mathrm{AH}$ after the decrystallization. With this, it is proved that the technique of high current pulses in restoring the Ni-Cd battery capacity is reliable.

\section{CONCLUSION}

Based on the results discussed, the de-crystallization of Ni-Cd batteries with high current pulses managed enhanced the performance of the Ni-Cd battery as the discharge capacity is increased for $41 \%$ and the life cycles of the Ni-Cd battery is extended as the discharging time is improved 160 minutes.

At first, the period of the Ni-Cd battery usage is short due to the formation of crystalline that have accumulated on the surface of the battery plate during the process of charging and discharging process. Due to this crystalline formation, the internal resistance of the $\mathrm{Ni}-\mathrm{Cd}$ battery is high as the discharging time of the battery shorten and thus the performance of the battery declined.

However, with high current pulses the formation of the crystalline is capable to break. Consequently, the parameters of the Ni-Cd battery such as battery capacity, battery cell voltage and life cycle of the Ni-Cd battery is improved and the Ni-Cd battery is revived. Last but not least, the used technique is environmental friendly as it use electrical energy during the process of decrystallization.

\section{ACKNOWLEDGEMENTS}

The authors would like to express their gratitude to the Universiti Tun Hussein Onn Malaysia and Renewcell (M) Sdn. Bhd. This research is funded under MTUN Grant (Vot No. K118) and Industrial Grant (Vot No. M006).

\section{REFERENCES}

[1] Jian, G., Sen, B., Jian, C., Xianzhang, W., and Haifeng, X., "An Innovative VRLA Battery Solution for Energy Saving \& Emission Reduction,” Proc. 34thIEEE International Telecommunications Energy Conference, pp.1-5, 2012

[2] A. Khaligh, Z. Li, "Battery, ultracapacitor, fuel cell, and hybrid energy storage systems for electric, hybrid electric, fuel cell, and plug-in hybrid electric vehicles: State of the art," IEEE Transactions on Vehicular Technology, vol. 59, no. 6, pp. 28062814, 2010.

[3] G. Fontaras, et al., "Experimental evaluation of hybrid vehicle fuel economy and pollutant emissions over realworld simulation driving cycles," Atmospheric environment, vol. 42, no. 18, pp. 4023-4035, 2008

[4] Liang, TJ., et al., "Implementation of a regenerative pulse charger using hybrid buck-boost converter," in Power Electronics and Drive Systems 2001. Proceedings 4th IEEE International Conference, 2001.

[5] S. Matteson and E. Williams, "Residual learning rates in lead-acid batteries: Effects on emerging technologies," Energy Policy, vol. 85, pp. 71-79, 2015

[6] Paul Wolfram and Thomas Wiedmann, "Electrifying Australian transport: Hybrid life cycle analysis of a transition to electric light-duty vehicles and renewable electricity," Applied Energy, vol. 206, pp. 531-540, 2017.

[7] J. Peters, M. Baumann, B. Zimmermann, J. Braun, and M. Weil, "The environmental impact of Li-Ion batteries and the role of key parameters - A review," Renewable and Sustainable Energy Reviews, vol. 67, pp. 491-506, 2017.

[8] Cedric, C., et al., "Modeling and analysis of battery performance for renewable energy application," Proc. 15thEuropean Conference on Power Electronics and Applications, pp.1-10, 2013.

[9] Mariani, A., Thanapalan, K., Stevenson, P., and Williams, J., "Techniques for estimating the VRLA batteries ageing, degradation and failure modes," Proc. 19thInternational Conference on Automation and Computing, pp. 1-5, 2013.

[10] G. S. Glaize Christian, Lead and nickel electrochemical batteries, 1st ed. Great Britain and United States: ISTELtd and John Wiley, 2012.

[11] Zhang, J., J. Yu, C. Cha and H. Yang, "The effects of pulse charging on inner pressure and cycling characteristics of sealed Ni/MH batteries," J. Power Sources, vol. 136, pp. 180-185, 2004.

[12] Ayodele O. Soge and Paul W. Lefley, "Pulse charging of nickel-cadmium batteries for lost capacity recovery," Research Journal of Applied Sciences, Engineering and Technology, pp. 4934-4938, 2012.

[13] J. Vishnupriyan, R. Suganya. "Strategy for Ni-Cd battery performance improvement under deep cycling," IJAREEIE, vol. 4, no. 4, pp. 2196-2203, 2015

[14] Soeprapto Soeprapto, Rini Nur Hasanah, Taufik Taufik, "Battery management system on electric bike using lithium-ion 18650," International Journal of Power Electronics and Drive System (IJPEDS), vol. 10, no. 3, pp 1529-1537, 2019.

[15] Dirani, H. C., et al., "Impact of the current and the temperature variation on the Ni-Cd battery functioning," Technological Advances in Electrical, Electronics and Computer Engineering, pp. 339- 343, 2013. 
[16] Meekhun, D., Boitier, V., and Dilhac, J. M., "Charge and discharge performance of secondary batteries according to extreme environment temperatures," Proc. 35thIEEE Annual Conference on Industrial Electronics Conference, pp. 266-270, 2009.

[17] Jian, W., Zhengbin, W. Xianquan, D., Songhua, Q., and Xiaoping, Y., "Temperature characteristics improvement of power battery module for electric vehicles," Proc. IEEE International Conference on Vehicle Power and Propulsion Conference, pp.1-4, 2013.

[18] Sato, Y., S. Takeuchi, K. Kobayakawa, "Cause of the memory effect observed in alkaline secondary batteries using nickel electrode," J. Power Sources, vol. 93, no. 1-2, pp. 20-24, 2001.

[19] Huggins, R. A., "Mechanism of the memory effect in 'Nickel' electrodes," Solid State Ion, vol. 177, no. 26-32, pp. 2643-2646, 2006.

[20] P. Bača, P. Křivík, P. Tošer, and S. Vaculík, "Negative lead-acid battery electrodes doped with glass fibres," Int. J. Electrochem. Sci., vol. 10, no. 3, pp. 2206-2219, 2015.

[21] N. Sugumaran, P. Everill, S. W. Swogger, and D. P. Dubey, "Lead acid battery performance and cycle life increased through addition of discrete carbon nanotubes to both electrodes," Journal of Power Sources, vol. 279, pp. 281-293, 2015.

[22] Z. Wu, Y. Liu, C. Deng, H. Zhao, R. Zhao, and H. Chen, "The critical role of boric acid as electrolyte additive on the electrochemical performance of lead-acid battery," J. Energy Storage, vol. 27, pp. 1-7, 2020.

[23] A. Kozwa, S. Minami, S. J. Hou, I. Mizumoto, M. Yoshio, and J. C. Nardi, "Basic understanding of the low current charge and high current charge for lead-acid batteries," Journal of Asian Electric Vehicles, vol. 2, no. 1, pp. 577-578, 2004.

[24] Y. Zhang, S. Hou, S. Minami, and A. Kozawa, "A high current pulse activator for the prolongation of Lead-acid batteries," 2008 IEEE Veh. Power Propuls. Conf. VPPC 2008, pp. 3-6, 2008.

[25] Gani, A.F.H.A., Bakar, A. A., Ponniran, A., Hussainar, M., Amran, M.A.N., "Design and development of PWM switching for 5-level multiphase interleaved DC/DC boost converter using FPGA," Indonesian Journal of Electrical Engineering and Computer Science (IJEECS), vol. 17, no. 1, pp. 131-140, 2020.

[26] M. S Arifi, N. Mohammad, M. I. Khalil, M.J. Alam, "Input switched closed-loop single phase CUK AC to DC converter with improved power quality," International Journal of Power Electronics and Drive System (IJPEDS), vol. 10, no. 3, pp. 1373-1381, 2019.

[27] Ozdemir, A.T., Ustkoyuncu, N., Bakoglu, N.U., Ozsoy, F., Patat, S., "Temperature effects on calendar aging of lithium-ion and nickel metal hydride batteries," Proc. of the 1st International Conference on Design, Engineering and Computer Science, vol. 453, no. 1, 2018.

[28] Y. Li, et al., "A new perspective on battery cell balancing: Thermal balancing and relative temperature control," IEEE Energy Conversion Congress and Exposition (ECCE), pp. 1-5, 2016 